University of Arkansas, Fayetteville

ScholarWorks@UARK

Education Reform Faculty and Graduate

Students Publications

Education Reform

2-6-2019

\title{
An Evaluation of the Educational Impact of College Campus Visits:A Randomized Experiment
}

\author{
Elsie Swanson \\ University of Arkansas, Fayetteville \\ Katherine Kopotic \\ University of Arkansas, Fayetteville \\ Gema Zamarro \\ University of Arkansas, Fayetteville \\ Jonathan Mills \\ University of Arkansas, Fayetteville \\ Jay Greene \\ University of Arkansas, Fayetteville
}

See next page for additional authors

Follow this and additional works at: https://scholarworks.uark.edu/edrepub

Part of the Educational Assessment, Evaluation, and Research Commons, Educational Psychology Commons, and the Higher Education Commons

\section{Citation}

Swanson, E., Kopotic, K., Zamarro, G., Mills, J., Greene, J., \& Ritter, G. (2019). An Evaluation of the Educational Impact of College Campus Visits:A Randomized Experiment. Education Reform Faculty and Graduate Students Publications. Retrieved from https://scholarworks.uark.edu/edrepub/69

This Article is brought to you for free and open access by the Education Reform at ScholarWorks@UARK. It has been accepted for inclusion in Education Reform Faculty and Graduate Students Publications by an authorized administrator of ScholarWorks@UARK. For more information, please contact scholar@uark.edu. 


\section{Authors}

Elsie Swanson, Katherine Kopotic, Gema Zamarro, Jonathan Mills, Jay Greene, and Gary Ritter 


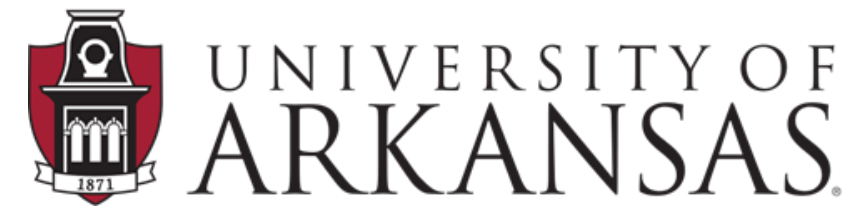

College of Education \& Health Professions Education Reform

\author{
WORKING PAPER SERIES
}

\title{
An Evaluation of the Educational Impact of College Campus Visits: \\ A Randomized Experiment
}

Elise Swanson, Katherine Kopotic, Gema Zamarro, Jonathan N. Mills, Jay P. Greene \& Gary
Ritter

February 5, 2019

EDRE Working Paper 2019-02

The University of Arkansas, Department of Education Reform (EDRE) working paper series is intended to widely disseminate and make easily accessible the results of EDRE faculty and students' latest findings. The Working Papers in this series have not undergone peer review or been edited by the University of Arkansas. The working papers are widely available, to encourage discussion and input from the research community before publication in a formal, peer-reviewed journal. Unless otherwise indicated, working papers can be cited without permission of the author so long as the source is clearly referred to as an EDRE working paper. 


\title{
char.asse.in
}

THE CHARACTER ASSESSMENT INITIATIVE

\section{An Evaluation of the Educational Impact of College Campus Visits:}

\section{A Randomized Experiment}

\author{
Elise Swanson, University of Arkansas* \\ Katherine Kopotic, University of Arkansas \\ Gema Zamarro, University of Arkansas \\ Jonathan N. Mills, University of Arkansas \\ Jay P. Greene, University of Arkansas \\ Gary Ritter, Saint Louis University
}

*Corresponding author. Elise Swanson, eswanson@uark.edu, 211 Graduate Education Building, University of Arkansas, Fayetteville, AR, 72701 


\begin{abstract}
We hypothesize that a lack of experience with college poses a non-trivial barrier to college access for historically underrepresented students. We study whether visits to a college campus during the eighth grade can reduce these psychological barriers to college access. Using an experimental design, we study whether college visits affect students' knowledge about college, postsecondary intentions, college-going behaviors, academic engagement, and ninth grade course enrollment decisions. We recruited 885 students across 15 schools who participated in our project during the academic year 2017-2018. We randomized students within schools to either a treatment or control condition. Students in the control condition receive an information packet about college. Students in the treatment condition receive the same information and visit a flagship university three times during their $8^{\text {th }}$-grade academic year. Students assigned to participate in these campus visits demonstrate higher levels of knowledge about college, higher levels of effort while completing the survey, a higher likelihood of having conversations with school personnel about college, and a decreased desire to attend technical school. Additionally, treated students are more likely to enroll in advanced math and science/social science courses in $9^{\text {th }}$ grade.
\end{abstract}

Keywords: college access; randomized experiment; campus visits; psychological barriers. JEL codes: I20, I23, J15 


\section{Introduction}

Increasing access to higher education is a serious policy concern at both the state and federal levels, given positive economic returns to postsecondary education (Oreopoulos \& Petronijevic, 2013) and the potential for postsecondary education to lead to social mobility (Chetty et al., 2017). While the total share of students entering higher education has increased since 2000 (National Center for Education Statistics, 2018), a 19-percentage point gap remains between the enrollment rates of would-be first-generation and continuing-generation students ${ }^{1}$ (Cataldi, Bennett, Chen, \& Simone, 2018). In this paper, we study the degree to which visits to a college campus during middle school can reduce barriers to college access, especially for historically underrepresented, would-be first-generation students.

Many policymakers and researchers have responded to the issue of inequitable college access largely by intervening with high school students and focusing on clear barriers to college access. For example, the state of Arkansas covers the cost of the ACT exam for all students and Tennessee offers full tuition for high school graduates who attend community colleges. While these interventions may help students who want to attend college but lack the means to do so, many students determine their postsecondary aspirations by their freshman or sophomore year (Hossler, Braxton, \& Coopersmith, 1989), and there are widening gaps in postsecondary aspirations between would-be first-generation and continuing-generation students that develop early in middle and high school (Anders \& Mickelwright, 2015). Thus, an intervention aimed at increasing students' motivation for postsecondary education before high school is particularly

\footnotetext{
${ }^{1}$ We define first-generation students as students whose parents have not received any type of postsecondary education. Continuing-generation students have at least one parent who has received some type of postsecondary education.
} 
well-situated to increase the pool of students who are interested in attending college and shape students' long-term educational decisions.

The psychological and sociological literature has long recognized that first-generation students may lack the "cultural capital," or cultural knowledge and social assets [Bourdieu, 1977], necessary for navigating universities' complex formal and informal systems they face when applying to and attending college (Swidler, 1986; Lareau, 1989; Collier \& Morgan, 2008; Hamilton, Roksa, \& Nielsen, 2018). Even if students possess the financial resources and information necessary to attend college, they may be less likely to enroll if they feel they would not belong on a college campus. Given how little exposure historically underrepresented students have to college campuses or to individuals who have had those experiences, the college environment might be very psychologically intimidating to these potential students. Di Maggio's (1982) cultural mobility theory posits that students can acquire cultural capital from outside the family, suggesting that a school-based intervention may be able to give students the necessary cultural capital to feel confident in preparing for, applying to, and being successful in an institution of higher education.

We examine the impact of three field trips to a college campus during the eighth grade using a randomized experimental design. Specifically, we provide randomly assigned treated students with information about postsecondary options and organized field trips that expose students to various aspects of college life, while randomly assigned control students receive packets with the same information at their schools. We hypothesize that the experience of visiting a college campus multiple times, interacting with students and faculty, and participating in college-readiness programming will have a greater impact on students' college-related decisions than simply receiving a packet of information with no follow-up or interpersonal 
interaction along with the information. This paper examines the immediate effects of these field trips on students' knowledge and attitudes towards college, school engagement, measures of noncognitive skills, as well as ninth grade course enrollment within one year of the intervention. Through survey instruments, we find that those assigned to participate in the field trips demonstrate higher levels of knowledge about college, higher levels of conscientiousness when completing the survey, a higher likelihood of having conversations with school personnel about college, and a decreased desire to attend technical school. Our analysis of students' ninth grade course enrollment indicates students assigned to the campus visits are more likely to enroll in accelerated math courses, such as pre-AP Algebra or pre-AP Geometry, and are more likely to enroll in accelerated science and social studies courses, such as pre-AP Biology or pre-AP Civics.

The rest of this paper proceeds as follows: Section II discusses commonly theorized barriers to college access and the impacts of interventions addressing those barriers, Section III describes our intervention, Section IV explains our analytic strategy and sample, Section V presents our results, and Section VI concludes.

\section{Prior Literature: Barriers to College Access and Potential Interventions}

Barriers to college entry identified in the literature fall generally into three categories: a lack of financial resources, a lack of information about college costs/benefits or the college application and matriculation processes, or a lack of preparation for college (Page \& ScottClayton, 2016). While interventions addressing these barriers have successfully increased postsecondary access, we hypothesize that a lack of familiarity with college experiences poses a non-trivial, yet often overlooked, barrier to entry. Further, prior interventions have focused primarily on high school students, when many students have already fallen off a college track 
while still in middle school (Wimberly \& Noeth, 2005), or on "promising" students, which could limit the magnitude of an intervention's impact (Seftor, Mamum, \& Schrim, 2009). We argue that intervening earlier, when students are in eighth grade, and with students of all academic backgrounds could increase the pool of students successfully preparing and eventually accessing college.

Numerous programs provide students with financial aid to make college affordable. Financial aid programs with various designs can increase college enrollment (Kane, 2003; Cornwell, Lee, \& Mustard, 2005; Cornwell, Mustard, \& Sridhar, 2006; Bettinger, 2004; Goldrick-Rab, Harris, Kelchen, \& Benson, 2012; Page, Iriti, Lowry, \& Anthony, 2018; Daugherty \& Gonzalez, 2016; Bartik, Hershebein, \& Lachoska, 2017; Swanson \& Ritter, 2018). However, financial aid is limited in terms of its ability to promote college access and success. First, students often must complete complicated paperwork to apply for the aid, which creates its own barriers, as discussed below. Importantly, financial aid is often awarded late in a student's journey to college - typically, students do not know whether or how much aid they will receive until after they have been accepted into a particular institution. This uncertainty may deter students from applying to universities with a high sticker cost or from accepting an offer of admittance (Kelchen \& Goldrick-Rab, 2015). Additionally, financial aid programs can induce under-matching, whereby students who would have been successful in four-year universities enroll in two-year colleges because of the available aid (Carruthers \& Fox, 2016).

Information failures can also derail a student's postsecondary plans. Students, particularly those from low-income families, may lack important information about the college application and matriculation processes, such as how to complete the Free Application for Federal Student Aid (FAFSA), or how to decide which colleges to apply to (Hoxby \& Avery, 2012; Avery \& 
Kane, 2014). Further, information failures, such as not knowing where to send proof of vaccinations, can still occur after a university admits a student, leading admitted students to fail to matriculate at their chosen university (Castleman \& Page, 2014). Providing students with information about the college application and matriculation processes can increase rates of applying to and enrolling in college (Barr \& Turner, 2017; Hoxby \& Turner, 2013; Page \& Gehlbach, 2017). Additionally, having current university students visit high schools to talk about the college process can increase enrollment at selective institutions (Sanders, 2018). However, like financial aid, interventions providing information are limited in the extent to which they can affect postsecondary decisions (Bettinger, Long, Oreopoulous, \& Sanbonmatsu, 2009), in part because they often lack meaningful interpersonal interactions (Carrell \& Sacerdote, 2017).

In addition to facing informational and monetary barriers, students may also struggle to matriculate at a postsecondary institution because of inadequate academic preparation (Avery \& Kane, 2014; Gonzalez, Bozick, Tharp-Taylor, \& Phillips, 2011). This problem may be particularly acute for would-be first-generation students; Cataldi et al. (2018) find that would-be first-generation students are less likely to take advanced math, AP, and IB courses in high school than continuing-generation students, even though these courses may be particularly useful for college applications.

While researchers consistently find that comprehensive interventions addressing overlapping barriers to college success increase postsecondary enrollment and persistence (Oreopoulos \& Petronijevic, 2016; Carrell \& Sacerdote, 2017; Castleman \& Goodman, 2018; Castleman \& Page, 2015; Oreopoulos, Brown, \& Lavecchia, 2014; Carruthers \& Fox, 2016), they are often difficult to scale, expensive, and tend to focus on high school upperclassmen. 
We hypothesize that a lack of cultural capital inhibits postsecondary access and completion for many students. Cultural capital (Bourdieu, 1977), includes knowledge such as understanding the usefulness of office hours and social assets such as having access to a professional network to find an internship, affects students' schooling outcomes, including academic performance, college enrollment, and educational attainment (Swidler, 1986; Lareau, 1989; Hamilton, Roksa, \& Nielsen, 2018). A lack of cultural capital and familiarity with college can alienate historically underrepresented students from postsecondary opportunities, leading students to eschew an academic track in high school, disengage from school, and attain and retain less information about how to obtain a postsecondary degree. Sociology cultural mobility theory (Di Maggio, 1982) argues that sources outside the family can promote cultural capital, suggesting that school-based interventions could increase college access by increasing students' cultural capital. The literature examining barriers to college access has largely overlooked a lack of cultural capital as an important barrier for students and few studies have examined whether school-based interventions aimed at increasing students' familiarity with college can impact students' postsecondary outcomes.

Although most interventions designed to improve college access focus on high school seniors, there is a reason to believe that intervening when students are in late middle school or early high school could benefit students' postsecondary outcomes. First, students begin making decisions that affect their postsecondary outcomes relatively early in their educational careers, including in middle school (Hossler, Braxton, \& Coopersmith, 1989; Wimberly \& Noeth, 2005; Klasik, 2012). Second, non-cognitive skills such as grit and conscientiousness seem malleable in early adolescence (Hoechsler, Balestra, \& Backes-Gellner, 2018), and are predictive of education attainment (Almlund, Duckworth, Heckman, \& Kautz, 2011; Hitt, Trivitt, \& Cheng, 2016) and 
career choices (Bandura, Barbaranelli, Caprara, \& Pastorelli, 2001). Third, and intuitively, intervening before students have made decisions about what courses to take in high school and before they have contributed to their high school GPA means that if the intervention changes students' aspirations, they will not have to make up for a low prior grade or regret having taken an additional study hall instead of a math class. However, a college-focused intervention that occurs too early could fail to resonate with the student, or the student could forget what they learned when they reach high school and start making college-relevant decisions. Thus, we argue that intervening when a student is in eighth grade could be particularly effective for altering students' postsecondary trajectories: they are close enough to high school for the information to resonate, but far enough away from postsecondary matriculation that all options are still open. In this paper, we test whether an early intervention (in eighth grade) aimed at increasing cultural capital (by familiarizing students with a college campus) can affect students' college knowledge and motivation, academic engagement, conversations about college with school personnel, and ninth grade course load. This work addresses two gaps in the literature: first, examining the extent to which a lack of familiarity with college presents a barrier to college access; and, second, examining whether a relatively early college-focused intervention, targeting the general population of eighth graders in a school, can affect students' college-going attitudes and decisions.

\section{Intervention}

Our intervention involved randomly assigning eighth grade students to one of two conditions. We arranged three field trips to a flagship public university for students in the treatment condition; the research team fully covered the cost of these trips, including transportation, meals, and chaperones. These visits represented various facets of the college 
campus experience and were designed to make students feel more comfortable being on a college campus as well as with the idea of one day being a college student. Additionally, students in both the treatment and control groups received college information packets at the beginning of the spring semester in 2018. We then tested the impact of visiting a college campus and receiving information relative to only receiving information about college on paper. We hypothesized that the acquisition of cultural capital through the concrete experience of visiting a college campus would leave a more profound and lasting impression on students than would easy access to written information about postsecondary options.

Specifically, we hypothesize that the field trips will increase students' knowledge of college above what students may learn from written materials about postsecondary options. We argue that having information delivered in person, from engaging presenters and particularly from current undergraduate students with similar backgrounds as participating students, will help students retain information better than having access to written information they may or may not read and engage with. Further, we hypothesize that as students interact with campus staff, faculty, and students in both formal and informal settings on campus, they may demonstrate an increase in perspective taking. Additionally, we think that hearing from students with similar backgrounds and learning of some of the support systems in place on campus for students will increase students' sense of college efficacy.

We also hypothesize that the field trips will positively affect students' academic engagement, conscientiousness, grit, self-management, and likelihood of enrolling in advanced coursework. We argue that if eighth grade students hear from university students about the amount of work, personal responsibility, and persistence it takes to be successful in college, they will be more engaged in school and seek out academic challenges in order to be better prepared 
for college. Further, we argue that, through their experiences with academic departments, students will gain a better understanding of the types of content they can study in college and the high expectations they will have to meet to be successful in college. Similarly, we hypothesize that if students are prompted to start thinking about what it will take to be prepared for college, they will be more likely to have additional conversations about college with school personnel, parents, and others who can advise them throughout the process of preparing for, applying to, and entering college. Finally, we hypothesize that students' increased familiarity with a college campus will help reduce psychological barriers to college, potentially shifting their postsecondary aspirations.

A brief description of each visit follows. For more detailed information, see Appendix A. Visit One: The first campus visit included a college information session and campus tour. Students arrived on campus and met with Student Ambassadors from the college admissions office for a tour that highlighted campus traditions, history, and unique buildings. The eighth graders then participated in a workshop developed by staff at the university's College Access Initiative that discussed what college is, how to succeed in college, and how to prepare for college. The students also learned skills that will set them up for success when applying to colleges, including study tips, the importance of enrolling in challenging classes and participating in extra-curricular activities in high school, and different resources available to them as high school students. The students also heard from current undergraduate students about their experiences and were able to ask questions about college life. To conclude the first visit, students ate lunch in an on-campus dining hall to familiarize them with a social aspect of campus life. 
Visit Two: The second visit to campus focused on exposing students to different departments and degree paths available at the university. Students took a tour of housing options available on campus, which included a model dorm room and common areas that are standard in community-style housing halls. Following their tour of housing, the students participated in an engineering presentation. Current students described various engineering subfields and their associated career paths. The engineering students then tasked the eighth graders with a construction challenge appropriate for their age. Following the engineering activity and lunch, students broke into smaller groups and visited one other department on campus ${ }^{2}$. The participating departments included English, architecture, economics, nursing, the Volunteer Action Center, astronomy, University Recreation, and theater. Each department organized a content-specific activity for the students ${ }^{3}$.

Visit Three: The final visit aimed to foster a sense of campus spirit. Participating school leaders chose to come with their students to either attend an official university baseball game held on a Saturday afternoon or to compete in an on-campus scavenger hunt organized by the research team.

Information Packet: All participating students, in both the treatment and control conditions, received an information packet at the beginning of the spring semester; for treated students, this fell between their second and third visits. The packet included a list of the postsecondary institutions in the state as well as their websites, physical locations, and contact information; a checklist of things to do in each grade in high school to prepare for college; and information about different types of occupations, including educational requirements and

\footnotetext{
${ }^{2}$ Students from large schools were able to choose which department they visited, while students from smaller schools remained as one group and all visited the same department. Departmental options varied by day, based on when faculty/graduate students within each department were available to host students.

${ }^{3}$ Detailed descriptions of each visit are available in Appendix A.
} 
expected salaries. All information provided in the information packet was available online. ${ }^{4}$ Finally, the folder included a personalized cover letter describing the information students received. Although the research team compiled the packets, school personnel distributed the folders.

\section{Sample and Analytic Strategy}

\section{A. Recruitment and Randomization}

Fifteen schools participated in this study in the 2017-18 school year. We initially reached out to schools within a two-hour drive of the university whose student bodies were comprised of at least 50 percent students of color or at least 60 percent students receiving free or reduced-price lunch. One district asked that we include all junior high schools in the district in the study; because of this request, we did include one school whose demographics were slightly more advantaged than we initially targeted.

The closest school to the university is within a 10-minute drive, while students at the farthest school have to travel about 90 minutes to reach campus. Schools vary greatly in size, with the total number of eighth-grade students within each school ranging from about 50 students to about 500 students. The share of students receiving free- or reduced-price lunch within each school ranges from 49 percent to 85 percent, while the share of students of color ranges from 6 percent to 85 percent. The majority of students in our sample are would-be first-generation college students; 66 percent of students report that neither of their parents holds a college degree, and only 13 percent of students report that both their parents have earned college degrees.

Slightly less than half of the students in our sample have never visited a college campus prior to

\footnotetext{
${ }^{4}$ Information on postsecondary options were available through the state's department of education. Preparation checklists were available here: https://www.petersons.com/blog/college-planning-timelines/. Information about career pathways was available here: https://www.bls.gov/k12/content/teachers/posters/posters.htm.
} 
this intervention, which is remarkable given the relative proximity of the schools to campus. Six schools are located in urban areas, while the remaining nine are in rural communities.

We use a straightforward block randomized experimental design for this analysis.

Students are randomly assigned to either the treatment (campus visits and information) or control (information only) group within their schools ${ }^{5}$.

\section{B. Data}

At the beginning of the 2017-18 school year, consent forms were sent home with all eighth-grade students in all participating schools. Across all 15 schools, 885 students agreed to participate in the study. We surveyed students at the beginning of the fall semester, prior to randomization, in order to collect baseline measures of student characteristics and outcome constructs; we were able to survey 88 percent of students who opted into the study. The surveys took students between 20 and 40 minutes to complete. At the end of the spring semester, after all the campus visits and after all students received the information packets, we surveyed participating students a second time in order to collect our outcome measures. We were able to survey 73 percent of participating students ${ }^{6}$. In this section, we describe our main outcome variables of interest derived from the student survey and show how our randomization procedure achieves balance on average observed characteristics between our treatment and control groups ${ }^{7}$.

\footnotetext{
${ }^{5}$ We used STATA's randomize command to run 100 randomizations within each school and automatically select the randomization that achieved the best balance on dichotomous indicators for student gender and race, as is recommended given the relative small number of students we observe within any given school (Bruhn \& McKenzie, 2009).

${ }^{6}$ Treated students were about $10 \%$ more likely to complete an end-of-year survey than control students, a difference that is statistically significant at the $90 \%$ confidence level. The overall and differential attrition rates we observe would still place this study within the liberal attrition standards declared by IES WWC standards for valid RCT studies (https://ies.ed.gov/ncee/wwc/Docs/referenceresources/wwc_brief_attrition_080715.pdf).

${ }^{7}$ All information related to student demographics and baseline attitudes towards college are drawn from our fall (pre-randomization) survey; we are not able to test for balance for students who did not complete an initial survey. Students who did not complete a survey were still randomized to either the treatment or control condition. We attempted to survey all students at the end of the year who participated in the project, including those who did not complete a baseline survey. Sixty-six students (7\% of our sample) completed a spring survey but did not complete a baseline survey.
} 
Our first outcome of interest is students' knowledge of basic, college-related, information because we anticipate that the excitement of visiting a college campus will help students retain more information than simply receiving the information on paper in school. In the baseline survey, students are assigned one of two versions of a set of 14 college knowledge questions. Each set consists of a series of true or false and multiple choice questions that asked, for example, about what type of courses available to students in high school could result in college credit and the main difference between community colleges and four-year universities. All students respond to the same 11 items on the spring survey, four of which were new to the knowledge construct. The spring survey questions include both yes/no questions but also some open-ended questions. Topics covered in these questions include the difference between community colleges and four-year universities, the average cost of attendance for an in-state student at the state's flagship university, and which factors universities typically consider when making admissions decisions.

All the knowledge questions are original to this project. Thus, we use item response theory to test the extent to which our knowledge questions discriminate among different levels of knowledge about college and are appropriately difficult for students in our sample. Our analyses indicate six items on our baseline survey and four questions in the spring survey were not able to discriminate in our sample and were eliminated from our college knowledge measure. We then build measures of knowledge about college for the baseline and spring surveys as the percentage of correct responses on a scale from zero to one, with one indicating a 100 percent correct ${ }^{8}$.

\footnotetext{
${ }^{8}$ We randomly assigned students to one of two versions of the knowledge questions on the fall survey; we retained eight items from version A and five items from version B. All students responded to the same survey in the spring; we retained seven items for that analysis.
} 
The second set of outcome variables measures students' non-cognitive skills, also referred to as socioemotional skills, psychosocial skills, and character skills (Duckworth \& Yeager, 2015). We include two behavioral proxy measures of student conscientiousness through the effort students put forward on the surveys: careless answering (Hitt, 2015) and item nonresponse (Borghans \& Schils, 2012; Hitt, Trivitt, \& Cheng, 2016; Zamarro, Nichols, Duckworth, \& D'Mello, 2018). Recent literature has found that these survey effort measures are good proxy measures of character skills related to conscientiousness and are significant predictors of important academic and life outcomes (Marcus and Schütz, 2005; Hitt, 2015; Huang et al., 2012; Johnson, 2005; Meade and Craig, 2012; Zamarro et al., 2018). Additionally, we include selfreports of college efficacy (Gibbons \& Borders, 2010), grit (Duckworth, Peterson, Matthews, \& Kelly, 2007), self-management (Panorama, 2018), and perspective taking (Davis, 1980). Finally, we also include two original measures of academic engagement. We calculate Cronbach's alpha for each construct to check its reliability within our specific sample. Table 1 presents a summary of our constructs, including a sample item and Cronbach's alpha. All our constructs, except our second measure of academic engagement ${ }^{9}$, have an alpha of at least 0.6 , indicating that these scales present reasonable validity within our sample.

We next look at two initial measures of college-going behaviors aiming to capture the degree students have conversations about college with school personnel and parents. Our first scale measures the average frequency of conversations students report having with school personnel and combined students' responses across eight college dimensions: admissions requirements for two-year and four-year colleges, how to decide which college to attend, their

\footnotetext{
${ }^{9}$ The items included in this construct asked students about time use: "In a typical 7 day week during the school year, about how much time do you do the following outside of school? - Completing homework for class; Studying for tests or quizzes; and Reading for your own personal interest (books, magazines, newspapers, online articles, etc.”
} 
likelihood of being accepted to different types of schools, what ACT/SAT scores they will need gain admission into college, opportunities to go out-of-state, readiness for college-level coursework, study skills required for postsecondary education, and how to pay for college. Students respond on a zero (No), one (Yes, Once) to two (Yes, multiple times) scale. This scale presents high reliability in our sample with an alpha reliability coefficient of 0.8 . Our second measure is obtained from students' responses to a single item which asks if they have ever talked to their parents about college. Students, in this case, respond on a zero (Never), one (Once or twice), two (A few times) to three (All the time) scale.

We also study the effect of our intervention on students' reported postsecondary intentions. On the survey, we ask students the following question "If I had to decide right now, after I graduate high school, I plan to...". Students are given six options and are prompted to choose only one: attend a two-year or community college; attend a technical/vocational school; attend a four-year college; enter the military full-time; find a job, or other. We look at each of the five defined options as a dichotomous outcome to determine if the campus visits have affected students' likelihood of intending to follow each of these paths.

Additionally, students self-report their demographic information, including gender and ethnicity, participation in the federal TRIO program, prior exposure to college campuses, and current grades. We also include a measure of socioeconomic status based on the Programme for International Assessment (PISA)'s index of economic, social, and cultural status (OECD, 2012). Through our collection of administrative data from the schools, we are also able to complete missing responses on questions of student gender and race.

Finally, we use information from district administrative records to determine whether the program affects students' ninth-grade course-taking decisions. While the majority of courses 
students in ninth grade take are determined by the school, students are able to choose whether to take pre-Advanced Placement (AP) or honors courses instead of regularly-paced courses. We collect transcript information from participating schools to determine whether treated students are more likely to enroll in pre-AP or honors courses for their core subjects (math, English, and science/social studies) than control students. We code a course as "advanced" if it includes "advanced", "honors", "pre-AP", or "AP" in the course name the district provides. Given the data we observe, it appears every school offers advanced English courses in ninth grade, but four schools do not offer advanced math courses and a different set of four schools does not offer advanced science of social studies courses. Overall, $17 \%$ of participating students across all schools enroll in an advanced math course in the first semester of their ninth grade year, $26 \%$ enroll in an advanced English course, and 17\% enroll in an advanced science or social studies course.

Table 2 presents summary statistics and tests of balance for our sample that are based on our fall (baseline) survey. To test for within-school balance, we regress each variable on an indicator for treatment status and a vector of school indicators. As shown in Table 2, we achieve balance on all observed characteristics except our college efficacy construct. We see that, at baseline, students who are later randomized to participate in the campus visits report higher feelings of efficacy by 0.08 points on a four-point Likert scale. Note, however, that we are performing multiple hypothesis tests in our check for balance, so we would expect about one false positive given a five percent Type I error rate. However, to be conservative, we present estimated effects of the intervention controlling for baseline measures of college efficacy as a robustness check. 


\section{Empirical Approach}

We estimate the intent-to-treat (ITT) effects of the campus visits relative to only receiving an information packet. Reports from school staff indicate limited absences for the first two visits; however, poor weather conditions led to relatively low attendance rates for the third visit $^{10}$. Given these absences, our ITT estimates represent lower bounds of the effects of the intervention. Our main empirical model is as follows:

$$
Y_{i}=\beta_{0}+\beta_{1} T_{i}+\tau_{s}+\varepsilon_{i s}(1)
$$

Our outcome variable, $Y_{i}$, is, in turn, two self-reported scales of academic engagement, two behavioral proxy measures of conscientiousness, self-reported college efficacy, college knowledge, self-reported grit, self-reported perspective taking, and self-reported selfmanagement. In our analysis of ninth grade course enrollment, $Y_{i}$ is a dichotomous variable indicating whether or not the student enrolls in at least one accelerated course in the fall semester of their ninth grade year as well as at least one accelerated course in the areas of math, English and, science/social science separately. $T_{i}$ is a dichotomous variable indicating whether student $i$ is assigned to participate in the field trips, $\tau_{s}$ is a vector of school fixed effects, and $\varepsilon_{i s}$ is a stochastic error term clustered at the school level.

Our coefficient of interest $\beta_{1}$ captures the causal relationship between being assigned to participate in the field trips and our outcome of interest. Given our randomized experimental design, our model should not need further demographic controls to estimate the causal effect of being assigned to attend the campus visits. Further, as we demonstrate above, our treatment and control groups are generally balanced on observable characteristics and so we do not suspect there would be a reason for the two groups to differ on any unobserved characteristics. As a

\footnotetext{
${ }^{10}$ Unfortunately, we do not have detailed records that would allow us to estimate dosage effects of attending all three visits instead of one or two visits.
} 
robustness check, however, in Appendix B we also present results for all analyses in which we control for student race and gender. Results were similar to the ones we present here without such controls.

One potential threat to the validity of our experimental design is the possibility of treatment crossover, whereby students not assigned to the visits decide to visit a college campus on their own. However, the programming students participate in through this project is in many ways unique, limiting the concern that students will simply access the full treatment experience on their own. Additionally, we ask students on our baseline and spring survey whether they have visited a college campus. Despite being within a relatively easy driving distance of the state's flagship university, we find that, at baseline, 44 percent of responding students report never having visited a college campus. In the spring, 33 percent of responding students from the control group report never having visited a college campus, compared to less than five percent of responding students from the treatment group. While the treatment may have induced some control students to visit a college campus on their own, we still have a distinct treatment-control contrast for our analysis.

Our outcome measures in this paper are derived from student responses on the spring survey as well as administrative records as described in section IV. B. above. These measures are summarized in Table 3. Note that our outcome variables are measured on different scales. Careless answering is a standardized measure, item non-response and college knowledge are percentages (share of skipped items or share of correct responses, respectively), self-reported non-cognitive skills are on scales of one to four or one to five, postsecondary intentions are dichotomous variables, and conversations with school personnel and parents are on zero to two and zero to three scales, respectively. 


\section{Results}

We first present results from our analysis of the student survey administered in the spring of the 2017-18 school year, about three months after students received the information packets and about one month after the final campus visit ${ }^{11}$. Table 4 presents results from our model, described in equation (1), which includes an indicator for treatment assignment and school fixed effects. We find that being assigned to the visits leads to a 3.3 percent ( 0.1 standard deviations) significant increase in the share of correct responses on the college knowledge section of the survey relative to being assigned to receive just a packet of information about postsecondary options and preparation at school.

Being assigned to attend the campus visits also leads to a 9.7 percent $(0.2$ standard deviations) reduction in item non-response behavior on the spring survey, an effect that is statistically significant at the 90 percent confidence level. When students visit campus, they hear from current undergraduates about the importance of time management, attention to detail, persistence, and responsibility for college success. Additionally, on their second visit, students complete intricate, challenging tasks with different departments. These experiences could lead to an increase in conscientiousness as we observe based on proxy measures through item nonresponse rates.

We also find that students assigned to the campus visits increase their reports of conversations with school staff about college. We find a statistically significant increase in the frequency of conversations of 0.07 points ( 0.1 standard deviations). This increase in the likelihood and number of conversations about college could push students to take more "college

\footnotetext{
${ }^{11}$ Depending on school, the fall survey was administered in August or September 2017 while the spring survey was administered in April or May 2018.
} 
preparatory" courses, learn more about various college options, and ultimately find a better match for their postsecondary institution.

Finally, we find that participating in the visits leads to a 3.4 percentage point decrease in the likelihood a student will report planning to attend a technical school after graduating from high school. However, there is no corresponding significant increase in the likelihood of intending to find a job, enter the military, attend a community college, or attend a 4-year university. Further, only about two percent of students overall in the spring indicated they intend to attend a technical school, so a decrease of three percentage points is a small shift. We find no impact of the field trips on our other measures of non-cognitive skills, behaviors, or intentions.

In our test for baseline balance within schools, described in section IV.B, we see that students later assigned to participate in the campus visits report slightly higher feelings of college efficacy at baseline. Thus, as a robustness check, we run the same parsimonious model but control for baseline reports of college efficacy in addition to treatment assignment and school fixed effects. Standard errors are again clustered at the school level. Our results, presented in Table 5, are largely consistent with the findings from our main model. We find a significant, positive impact of the visits on students' college knowledge, although it is slightly larger in magnitude than the effect from our preferred specification (4.6 percent as opposed to 3.3 percent). Similarly, we find a slightly larger reduction in item non-response (11.5 percent as opposed to 9.7 percent) when controlling for baseline college efficacy; this effect remains statistically significant. We also continue to see a slight reduction (3.5 percent) in the likelihood that a student reports intending to attend a technical school after high school; this effect is significant when controlling for baseline college efficacy. However, when we control for baseline college efficacy, we no longer see a significant impact of the trips on the likelihood or 
frequency that a student will engage in conversations about college with school personnel. The point estimate remains positive ( 0.05 points on a three-point scale), but it is not statistically significant at conventional levels. We continue to see no statistically significant impacts of the intervention on our other measures of student non-cognitive skills, postsecondary intentions, or behaviors.

We turn now to our analysis of students' ninth-grade course enrollment decisions. We have administrative data from 14 of our 15 participating schools. We began with 780 students enrolled in those 14 schools and we were able to collect transcript information for 708 (91\%) of those students. We also observe little differential attrition in the administrative data based on treatment status; $92 \%$ of treated students are observed in the administrative data, as are $89 \%$ of control students.

We use an analogous model for our analysis of course-taking as we did for the analysis of our survey-based outcomes, including school fixed effects and an indicator for whether or not the student is assigned to participate in the campus visits. These results are presented in the top panel of Table 6. We find that students assigned to the campus visits are 6.4 percentage points more likely to enroll in advanced math coursework than are students who only received written information about postsecondary preparation and options. Additionally, we find that students assigned to the campus visits are 6.1 percentage points more likely to enroll in advanced science or social studies courses than students who only received the information packet. Both effects are statistically significant at the $90 \%$ confidence level. We find no statistically significant impact of the visits on the likelihood that students enroll in advanced English coursework or on the likelihood that they enroll in any type of advanced coursework when courses are aggregated together. In the bottom panel of Table 6, we add a control variable for baseline college efficacy. 
When we include this control, we see no statistically significant impact of the campus visits on students' ninth grade course-taking. Effects remain positive but their size is smaller once we control for college self-efficacy.

\section{Discussion and Conclusion}

Postsecondary access is a concern for policymakers, researchers, and individual students across the country. Past work has focused on the role of financial aid, information, and assistance navigating bureaucratic processes, and relatively little work has examined the role of a lack of experience with college in students' postsecondary planning processes. In this study, we provide some of the first scientifically rigorous evidence that efforts to improve students' cultural capital through field trips to a college campus could improve students' knowledge about college and academic diligence (measured by item non-response) above the effect of providing information about college. We also find that campus visits may make students more likely to engage in conversations about college options and preparation with school personnel. Further, we find suggestive evidence that students assigned to the campus visits are more likely to enroll in advanced courses in math and science/social studies.

As one of the first experimental evaluations of an experience-based intervention aimed at improving students' college-going outcomes, this study makes an important contribution to the literature and our understanding of the barriers students face when making postsecondary decisions. However, given the preliminary and exploratory nature of this work, there are also several limitations of the current study that should be addressed in future work.

First, given the lack of research examining the impact of experiences on students' college-related outcomes, this study is largely exploratory. As a result, we did not want to curtail the outcomes we examined and are testing multiple outcomes, which raises the concern that we 
may see false positives in our models. Given the number of hypotheses we are testing, we would expect to have two false positive results at the $90 \%$ confidence level; we observe six significant effects, giving us some confidence that our results are not simply statistical noise. Additionally, we are currently collecting data from a second cohort of students and will follow both cohorts throughout high school to collect a variety of outcome measures. By seeing whether our results are replicated across cohorts and whether our results are consistent over time, we will be able to feel more confident that we are estimating the true impact of the program.

Second, our analysis appears to be potentially underpowered. We have survey information from less than 650 students. Taking into account our block randomized design and observed R-squared values, our minimum detectable effect size is about 0.2 standard deviations, which is larger than the size of the effects we are currently estimating. Adding the second cohort of participants in future iterations of this paper will help us increase our sample and power.

Third, we find that the visits increased student conscientiousness, as proxied by item nonresponse rates, but had no impact on self-reported measures of seemingly related non-cognitive skills like grit. Given the experiences students had on their visits and the extent to which the various presenters and students with whom they interacted stressed the importance of diligence, responsibility, and time management, we believe it is possible that this intervention affected student academic diligence potentially not well captured in self-reported grit. The eight-item grit scale we use, while validated as a measure of grit, is not necessarily well-suited to detect changes over time within an individual (Duckworth \& Yeager, 2015), which could explain why we see no impact of the intervention on grit. It could also be that students who received the most exciting benefit of the project (the field trips) felt grateful to the research team (whom they had seen on each visit and who administered the baseline and end-of-year survey) and felt compelled to 
answer all items on the survey, rather than that they actually became more conscientious. In future work, as we collect more information on students, including attendance, course grades, and eventual college enrollment we will be able to better assess whether the field trips increased student academic diligence and conscientiousness or simply altered students' behavior on the survey.

Finally, we see no substantial impact of the intervention on students' postsecondary plans; we find a small decrease in students' likelihood of intending to attend technical school after high school, but no change in students' intentions of attending four or two year university, entering the military, or working. Following students longitudinally to observe actual postsecondary behaviors will help further study if our intervention had an effect on postsecondary intentions despite not being able to capture an effect on our survey measures. Additionally, it should be pointed out that all students in our study volunteered to participate in a project that offered them a chance to visit a four-year university campus three times. Over half of our sample (56.6\% of students) aspired to attend a four-year university at baseline, potentially limiting our ability to detect a shift in college aspirations.

In order to close opportunity gaps in postsecondary enrollment and degree completion, researchers should find scalable interventions that can be implemented with fidelity across a variety of contexts. In this study, we explore the ability of a relatively low-cost interventionthree field trips to a local public university — to impact student attitudes and behaviors towards college. Both school districts interested in promoting college access for their students and universities interested in increasing their socioeconomic diversity or student population overall could easily adopt the approach we lay out in this intervention. While we cannot draw any strong 
conclusions from these preliminary findings given our limited sample size, our results suggest that such an intervention could have a meaningful impact on students. 


\section{References}

Almlund, M., Duckworth, A. L., Heckman, J. J., \& Kautz, T. D. (2011). Personality psychology and economics. Handbook of the Economics of Education. Vol. 4, 1-181.

Anders, J., \& Micklewright, J. (2015). Teenagers' expectations of applying to university: How do they change? Education Sciences, 5, 281-305. Doi: 10.3390/educsci5040281.

Avery, C., \& Kane, T. (2014). Student perceptions of college opportunities: The Boston COACH program. In C. Hoxby (Ed.) College Choices: The Economics of Where to Go, When to Go, and How to Pay for It. Chicago, IL: University of Chicago Press.

Bandura, A., Barbaranelli, C., Caprara, G., \& Pastorelli, C. (2001). Self-efficacy beliefs as shapers of children's aspirations and career trajectories. Child Development, 72(1), 187206.

Barr, A. \& Turner, S. (2017). A letter of encouragement: does information increase postsecondary enrollment of UI recipients? (NBER Working Paper No. 23374). Cambridge, MA: National Bureau of Economic Research.

Bartik, T., Hershbein, B., \& Lachowska, M. (2017). The effects of the Kalamazoo promise scholarship on college enrollment, persistence, and completion. Upjohn Institute Working Paper 15-229.

Bettinger, E. (2004). How financial aid affects persistence. (NBER Working Paper No. 10242). Cambridge, MA: National Bureau of Economic Research.

Bettinger, E., Long, B., Oreopoulos, P., \& Sanbonmatsu, L. (2009). The role of simplification and information in college decisions: results from the H\&R Block FAFSA experiment. (NBER Working Paper No. 15361). Cambridge, MA: National Bureau of Economic Research. 
Borghans, L., \& Schils, T. (2012). The Leaning Tower of Pisa: decomposing achievement test scores into cognitive and noncognitive components. Retrieved from: https://www.solejole.org/13260.pdf

Bourdieu, P. (1977). Outline of a Theory of Practice. Cambridge: Cambridge University Press.

Bruhn, M., \& McKenzie, D. (2009). In pursuit of balance: randomization in practice in development field experiments. American Economic Journal: Applied Economics, 1(4), 200-232. Doi: 10.1257/app.1.4.200.

Carrell, S. \& Sacerdote, B. (2017). Why do college-going interventions work? American Economic Journal: Applied Economics 2017, 9(3), 124-151.

Carruthers, C. \& Fox, W. (2016). Aid for all: College coaching, financial aid, and post-secondary persistence in Tennessee. Economics of Education Review, 51(2016), 97-112.

Castleman, B., \& Goodman, J. (2018). Intensive college counseling and the enrollment and persistence of low income students. Education Finance and Policy, 13(1), 19-41.

Castleman, B., \& Page, L. (2014). A trickle or a torrent? Understanding the extent of summer “melt” among college-intending high school graduates. Social Science Quarterly, 95(1), 202-220.

Castleman, B., \& Page, L. (2015). Summer nudging: Can personalized text messages and peer mentor outreach increase college going among low-income high school graduates? Journal of Economic Behavior \& Organization, 115(2015), 144-160.

Cataldi, E., Bennett, C., Chen, X., \& Simone, S. (2018). First-generation students: College access, persistence, and postbachelor's outcomes. National Center for Education Statistics: U.S. Department of Education. 
Chetty, R., Friedman, J., Saez, E., Turner, N., \& Yagan, D. (2017). Mobility report cards: The role of colleges in intergenerational mobility. Retrieved from: http://www.equality-ofopportunity.org/papers/coll_mrc_paper.pdf

Collier, P., \& Morgan, D. (2008). “Is that paper really due today?”: Differences in firstgeneration and traditional college students' understandings of faculty expectations. Higher Education, 55(4), 425-446.

Cornwell, M., Lee, K., \& Mustard, D. (2005). Student responses to merit scholarship retention rules. The Journal of Human Resources, 40(4), 895-917.

Cornwell, M., Mustard, D., \& Sridhar, D. (2006). The enrollment effects of merit-based financial aid: evidence from Georgia’s HOPE program. Journal of Labor Economics, 24(4), 761786.

Daugherty, L. \& Gonzalez, G. (2016). The impact of the New Haven promise program on college enrollment, choice, and persistence. RAND Education Working Paper 1146. Retrieved from http://www.rand.org/pubs/working_papers/WR1147.html

Davis, M.H. (1980). A multidimensional approach to individual differences in empathy. Catalog of Selected Documents in Psychology. Retrieved from https://www.uv.es/friasnav/Davis_1980.pdf

Di Maggio, P. (1982). Cultural capital and school success: the impact of status culture participation on the grades of U.S. high school students. American Sociological Review, 47, 189-201.

Duckworth, A., Peterson, C., Matthews, M. \& Kelly, D. (2007). Grit: Perseverance and passion for long-term goals. Journal of Personality and Social Psychology, 92(6), 1087-1101. 
Duckworth, A. \& Yeager, D.S. (2015). Measurement matters: Assessing personal qualities other than cognitive ability for educational purposes. Educational Researcher, 44(4), 237-251.

Gibbons, M. \& Borders, L. (2010). A measure of college-going self-efficacy for middle school students. ASCA, 13(4), 234-243.

Goldrick-Rab, S., Harris, D., Kelchen, R., \& Benson, J. (2012). Need-based financial aid and college persistence: experimental evidence from Wisconsin. Wisconsin Scholars Longitudinal Study. Retrieved from: http://www.finaidstudy.org/documents/goldrickrab\%20harris\%20benson\%20kelchen.pdf.

Gonzalez, G., Bozick, R., Tharp-Taylor, S., \& Phillips, A. (2011). Fulfilling the Pittsburgh promise: Early progress of Pittsburgh's postsecondary scholarship program. Santa Monica, CA: RAND Corporation. Retrieved from: https://www.rand.org/content/dam/rand/pubs/monographs/2011/RAND_MG1139.pdf

Hamilton, L., Roksa, J., \& Nielsen, K. (2018). Providing a "leg up": Parental involvement and opportunity hoarding in college. Sociology of Education, 91(2), 111-131.

Heckman, J., Stixrud, J., \& Urzua, S. (2006). The effects of cognitive and non-cognitive abilities on labor market outcomes and social behavior. Journal of Labor Economics, 24(3), 411482.

Hitt, C. (2015). Just filling in the bubbles: Using careless answer patterns on surveys as a proxy measure of noncognitive skills. EDRE working paper 2013-05. Retrieved from http://www.uaedreform.org/downloads/2015/07/edre-working-paper-2015-06.pdf

Hitt, C. Trivitt, J., \& Cheng, A. (2016). When you say nothing at all: The predictive power of student effort on surveys. Economics of Education Review, 52(2016), 105-119. 
Hoechsler, P., Balestra, S., \& Backes-Gellner, U. (2018). The development of non-cognitive skills in adolescence. Economics Letters, 163(2018), 40-45.

Hossler, D., Braxton, J., \& Coopersmith, G. (1989). Understanding student college choice. In J. Smart (Eds.), Higher Education: Handbook of Theory and Research Volume V (pp. 230288). New York City, NY: Agathon Press.

Hoxby, C. \& Turner, S. (2013). Informing students about their college options: A proposal for broadening the expanding college opportunities project. The Hamilton Project, Brookings.

Hoxby, C. \& Avery, C. (2012). The missing "one-offs": The hidden supply of high-achieving, low income students. NBER Working Paper 18586. Cambridge, MA: National Bureau of Economic Research.

Huang, J., Curran, P., Keeney, J., Poposki, E., \& DeShon, R. (2012). Detecting and deterring insufficient effort responding to surveys. Journal of Business and Psychology, 27(1), 99114.

Johnson, J. (2005). Ascertaining the validity of individual protocols from web-based personality inventories. Journal of Research in Personality, 39, 103-129.

Kane, T. (2003). A quasi-experimental estimate of the impact of financial aid on college-going. (NBER Working Paper No. 9703). Cambridge, MA: National Bureau of Economic Research.

Kelchen, R. \& Goldrick-Rab, S. (2015). Accelerating college knowledge: A fiscal analysis of a targeted early commitment Pell grant program. The Journal of Higher Education, 86(2), 199-132. 
Klasik, D. (2012). The college application gauntlet: A systematic analysis of the steps to fouryear college enrollment. Research in Higher Education, 53(5), 506-549.

Lareau, A. (1989). Home Advantage: Social Class and Parental Intervention in Elementary Education. Rowman \& Littlefield Publishers, Inc.

Marcus, B. \& Schütz, A. (2005). Who are the people reluctant to participate in research? Personality correlates of four different types of nonresponse as inferred from self- and observer ratings. Journal of Personality, 73, 959-984.

Meade, A. \& Craig, S. (2012). Identifying careless responses in survey data. Psychological Methods, 17(3), 437-455.

OECD (2012). OECD Programme for International Student Assessment 2012. Student Questionnaire. Retrieved from https://nces.ed.gov/surveys/pisa/pdf/MS12_StQ_FormB_ENG_USA_final.pdf

Oreopoulos, P. \& Petronijevic, U. (2013). Making college worth it: A review of the returns to higher education. Future of Children, 23(1), 41-65.

Oreopoulos, P., Brown, R., \& Lavecchia, A. (2014). Pathways to education: an integrated approach to helping at-risk high school students. (NBER Working Paper No. 20430). Cambridge, MA: National Bureau of Economic Research.

Oreopoulos, P. \& Petronijevic, U. (2016). Student coaching: How far can technology go? NBER Working Paper 22630. Cambridge, MA: National Bureau of Economic Research.

National Center for Education Statistics (2018). College Enrollment Rates. The Condition of Education. Retrieved from https://nces.ed.gov/programs/coe/indicator_cpb.asp

Page, L. \& Gehlbach, H. (2017). How an artificially intelligent virtual assistant helps students navigate the road to college. AERA Open, 3(4), 1-12. 
Page, L. \& Scott-Clayton, J. (2016). Improving college access in the United States: Barriers and policy responses. Economics of Education Review, 51(2016), 4-22.

Page, L., Iriti, J., Lowry, D., \& Anthony, A. (2018). The promise of place-based investment in postsecondary access and success: Investigating the impact of the Pittsburgh promise. Education Finance and Policy (forthcoming).

Panorama Education (2018). Social-Emotional Learning: User Guide. Available from www.panorama.com

Sanders, M. (2018). Role models, mentoring, and university applications: Evidence from a crossover randomised controlled trial in the United Kingdom. Widening Participation and Lifelong Learning, 20(4), 57-80.

Seftor, N., Mamun, A., \& Schirm, A. (2009). The impacts of regular Upward Bound on postsecondary outcomes 7-9 years after scheduled high school graduation. Washington, D.C.: Mathematica Policy Research Inc.

Swanson, E., \& Ritter, G. (2018). Start to finish: Examining the impact of the El Dorado promise on postsecondary outcomes. EDRE Working Paper 2018-02.

Swidler, A. (1986). Culture in action: symbols and strategies. American Sociological Review, 51(2), 273-286.

Wimberly, G. \& Noeth, R. (2005). College readiness begins in middle school. ACT Policy Report. Retrieved from: http://citeseerx.ist.psu.edu/viewdoc/download?doi=10.1.1.508.5566\&rep=rep1\&type=pdf

Zamarro, G., Nichols, M., Duckworth, A., \& D’Mello, S. (2018). Further validation of survey effort measures of relevant character skills: Results from a sample of high school 
students. EDRE Working Paper 2018-07. Retrieved from

https://papers.ssrn.com/sol3/papers.cfm?abstract_id=3265332 


\section{Tables}

Table 1: Reliability of Scales (Spring Survey)

\begin{tabular}{|c|c|c|c|}
\hline Construct & Number of Items & Sample Item & Alpha \\
\hline College Efficacy & 14 & $\begin{array}{r}\text { "I can choose the high school classes needed to get } \\
\text { into a good college" }\end{array}$ & 0.9127 \\
\hline Grit & 8 & "I finish whatever I begin" & 0.6204 \\
\hline Self-Management & 10 & $\begin{array}{r}\text { "During the past } 30 \text { days, how often did you keep your } \\
\text { temper in check?" }\end{array}$ & 0.8572 \\
\hline Perspective Taking & 7 & $\begin{array}{c}\text { "I believe that there are two sides to every question } \\
\text { and try to look at them both" }\end{array}$ & 0.7340 \\
\hline Academic Engagement 1 & 5 & "I feel proud being a part of this school" & 0.6993 \\
\hline Academic Engagement 2 & $3^{12}$ & $\begin{array}{l}\text { "In a typical } 7 \text { day week during the school year, about } \\
\text { how much time do you do the following outside of } \\
\text { school? - Completing homework for class" }\end{array}$ & 0.5661 \\
\hline
\end{tabular}

\footnotetext{
${ }^{12}$ Our survey included four items, but we excluded one item ("What are your current grades?") to increase the construct's internal reliability.
} 
Table 2: Within-School Baseline Balance

\begin{tabular}{|c|c|c|c|c|c|c|c|}
\hline & $\mathbf{N}$ & Mean $^{\wedge}$ & $\begin{array}{r}\text { Standard } \\
\text { Deviation }^{\wedge}\end{array}$ & Min & $\operatorname{Max}$ & $\begin{array}{c}\text { "Effect" of } \\
\text { Treatment }^{\wedge \wedge}\end{array}$ & P-Value \\
\hline \multicolumn{8}{|l|}{ Student Demographics } \\
\hline Female & 762 & 0.585 & 0.493 & 0 & 1 & 0.004 & 0.914 \\
\hline White & 767 & 0.584 & 0.493 & 0 & 1 & -0.005 & 0.875 \\
\hline Black & 767 & 0.022 & 0.147 & 0 & 1 & 0.008 & 0.435 \\
\hline Latino/a & 767 & 0.261 & 0.439 & 0 & 1 & -0.016 & 0.580 \\
\hline Other & 767 & 0.133 & 0.340 & 0 & 1 & 0.013 & 0.583 \\
\hline SES & 612 & 0.000 & 1.000 & -3.354 & 2.180 & 0.057 & 0.463 \\
\hline \multicolumn{8}{|l|}{ College-Going Behaviors/Intentions } \\
\hline TRiO Participation & 764 & 0.205 & 0.404 & 0 & 1 & 0.019 & 0.498 \\
\hline Prior Exposure to a College Campus & 770 & 0.558 & 0.497 & 0 & 1 & -0.019 & 0.601 \\
\hline Plans to Enter 4-Year College after HS & 769 & 0.640 & 0.480 & 0 & 1 & 0.040 & 0.232 \\
\hline Talked about College w/ School Staff & 772 & 0.570 & 0.455 & 0 & 2 & 0.036 & 0.271 \\
\hline Talked about College w/ Parents & 772 & 1.904 & 0.824 & 0 & 3 & 0.089 & 0.132 \\
\hline Current Grades (1=F's; 5=A's) & 765 & 4.603 & 0.615 & 1 & 5 & 0.005 & 0.902 \\
\hline \multicolumn{8}{|l|}{ College Knowledge } \\
\hline College Knowledge & 693 & 0.541 & 0.186 & 0 & 1 & -0.013 & 0.337 \\
\hline \multicolumn{8}{|l|}{ Non-Cognitive Skills } \\
\hline College Efficacy & 774 & 2.965 & 0.544 & 1 & 4 & 0.081 & $0.036 * *$ \\
\hline Grit & 769 & 3.137 & 0.478 & 1 & 5 & 0.013 & 0.701 \\
\hline Self-Management & 763 & 4.159 & 0.557 & 1 & 5 & 0.024 & 0.544 \\
\hline Perspective-Taking & 759 & 3.395 & 0.696 & 1 & 5 & 0.052 & 0.299 \\
\hline Academic Engagement & 774 & 2.072 & 0.686 & 1 & 5 & 0.007 & 0.882 \\
\hline
\end{tabular}

Mean and standard deviation calculated across schools

${ }^{\wedge}$ Each baseline variable regressed on treatment status and school indicators to test for baseline balance 


N Mean $\begin{gathered}\text { Standard } \\ \text { Deviation }\end{gathered} \quad$ Min Max

Non-Cognitive Skills

\begin{tabular}{rrrrrr} 
Careless Answering & 646 & 0.000 & 1.000 & -4.510 & 2.680 \\
Item Non-Response & 885 & 0.275 & 0.442 & 0 & 1 \\
College Efficacy & 646 & 2.959 & 0.592 & 1 & 4 \\
Grit & 641 & 3.218 & 0.519 & 1 & 5 \\
Self-Management & 641 & 4.073 & 0.646 & 1.444 & 5 \\
Perspective-Taking & 642 & 3.355 & 0.691 & 1 & 5 \\
(Hmwk, Study, Read) & 645 & 1.939 & 0.755 & 1 & 4 \\
\hline
\end{tabular}

Postsecondary Plans

\begin{tabular}{rlllll} 
Find a Job & 631 & 0.090 & 0.287 & 0 & 1 \\
Enter the Military & 631 & 0.041 & 0.199 & 0 & 1 \\
Community College & 631 & 0.111 & 0.314 & 0 & 1 \\
a Technical School & 631 & 0.021 & 0.142 & 0 & 1 \\
\hline
\end{tabular}

Pro-College Actions

\begin{tabular}{rrrrrr} 
Talked about College w/ School Staff & 645 & 0.950 & 0.540 & 0 & 2 \\
Talked about College w/ Parents & 643 & 1.956 & 0.836 & 0 & 3 \\
\hline
\end{tabular}

\section{College Knowledge}

\begin{tabular}{llllll} 
College Knowledge & 640 & 0.577 & 0.228 & 0 & 1 \\
\hline
\end{tabular}


Table 4: Impact of Campus Visits on Survey-Based Outcomes

\begin{tabular}{|c|c|c|c|c|}
\hline & $\begin{array}{r}\text { Control Mean } \\
\text { (S.D.) } \\
\end{array}$ & $\begin{array}{r}\text { Treatment Effect } \\
\text { (Cluster-Robust S.E) } \\
\end{array}$ & $\mathbf{N}$ & R-Squared \\
\hline \multicolumn{5}{|l|}{ College Knowledge } \\
\hline College Knowledge & $\begin{array}{r}0.558 \\
(0.230)\end{array}$ & $\begin{array}{r}0.033 * * \\
(0.015)\end{array}$ & 640 & 0.101 \\
\hline \multicolumn{5}{|l|}{ Non-Cognitive Skills } \\
\hline College Efficacy & $\begin{array}{r}3.201 \\
(0.876)\end{array}$ & $\begin{array}{r}0.047 \\
(0.055)\end{array}$ & 646 & 0.095 \\
\hline Grit & $\begin{array}{r}3.192 \\
(0.530)\end{array}$ & $\begin{array}{r}0.040 \\
(0.041)\end{array}$ & 641 & 0.034 \\
\hline Self-Management & $\begin{array}{r}4.057 \\
(0.656)\end{array}$ & $\begin{array}{r}0.021 \\
(0.054)\end{array}$ & 641 & 0.049 \\
\hline Perspective & $\begin{array}{r}3.365 \\
(0.700)\end{array}$ & $\begin{array}{r}-0.017 \\
(0.063)\end{array}$ & 642 & 0.036 \\
\hline Academic Engagement 1 & $\begin{array}{r}2.923 \\
(0.361)\end{array}$ & $\begin{array}{r}0.007 \\
(0.023)\end{array}$ & 643 & 0.039 \\
\hline Academic Engagement 2 & $\begin{array}{r}1.970 \\
(0.766)\end{array}$ & $\begin{array}{r}-0.061 \\
(0.057)\end{array}$ & 645 & 0.023 \\
\hline Careless Answering (Std) & $\begin{array}{r}-0.048 \\
(0.996)\end{array}$ & $\begin{array}{r}0.066 \\
(0.087)\end{array}$ & 646 & 0.075 \\
\hline Item Non-Response Rate ${ }^{\wedge}$ & $\begin{array}{r}0.325 \\
(0.465) \\
\end{array}$ & $\begin{array}{r}-0.097 * \\
(0.047) \\
\end{array}$ & 885 & 0.136 \\
\hline \multicolumn{5}{|l|}{ College-Going Behaviors } \\
\hline Conversations w/ School Staff & $\begin{array}{r}0.910 \\
(0.550)\end{array}$ & $\begin{array}{r}0.071 * * * \\
(0.019)\end{array}$ & 645 & 0.117 \\
\hline Conversations w/ Parents & $\begin{array}{r}1.933 \\
(0.805)\end{array}$ & $\begin{array}{r}0.043 \\
(0.053)\end{array}$ & 643 & 0.033 \\
\hline \multicolumn{5}{|l|}{ Postsecondary Intentions } \\
\hline Find a Job & 0.086 & $\begin{array}{r}0.009 \\
(0.021)\end{array}$ & 631 & 0.038 \\
\hline Enter the Military & 0.021 & $\begin{array}{r}0.039 \\
(0.023)\end{array}$ & 631 & 0.035 \\
\hline Attend a Technical School & 0.038 & $\begin{array}{r}-0.034 * * * \\
(0.011)\end{array}$ & 631 & 0.049 \\
\hline Attend a Community College & 0.117 & $\begin{array}{r}-0.011 \\
(0.020)\end{array}$ & 631 & 0.015 \\
\hline Attend a 4-Year University & 0.684 & $\begin{array}{r}0.003 \\
(0.037)\end{array}$ & 631 & 0.053 \\
\hline
\end{tabular}

$* p<0.1, * * p<0.05, * * * p<0.01$

School fixed effects included in all models

Standard errors clustered at the school level

${ }^{\wedge}$ Students completely missing a spring survey are included in this analysis 
Table 5: Impact of Campus Visits on Survey-Based Outcomes; Controlling for Baseline College Efficacy

\begin{tabular}{|c|c|c|c|c|}
\hline & $\begin{array}{r}\text { Control Mean } \\
\text { (S.D.) } \\
\end{array}$ & $\begin{array}{r}\text { Treatment Effect } \\
\text { (Cluster-Robust S.E) }\end{array}$ & $\mathbf{N}$ & R-Squared \\
\hline \multicolumn{5}{|l|}{ College Knowledge } \\
\hline College Knowledge & $\begin{array}{r}0.558 \\
(0.230) \\
\end{array}$ & $\begin{array}{r}0.046 * * \\
(0.018) \\
\end{array}$ & 572 & 0.145 \\
\hline \multicolumn{5}{|l|}{ Non-Cognitive Skills } \\
\hline College Efficacy & $\begin{array}{r}3.201 \\
(0.876)\end{array}$ & $\begin{array}{r}-0.002 \\
(0.05)\end{array}$ & 578 & 0.447 \\
\hline Grit & $\begin{array}{r}3.192 \\
(0.530)\end{array}$ & $\begin{array}{r}0.022 \\
(0.043)\end{array}$ & 573 & 0.057 \\
\hline Self-Management & $\begin{array}{r}4.057 \\
(0.656)\end{array}$ & $\begin{array}{r}-0.030 \\
(0.048)\end{array}$ & 573 & 0.136 \\
\hline Perspective & $\begin{array}{r}3.365 \\
(0.700)\end{array}$ & $\begin{array}{r}-0.058 \\
(0.064)\end{array}$ & 575 & 0.095 \\
\hline Academic Engagement 1 & $\begin{array}{r}2.923 \\
(0.361)\end{array}$ & $\begin{array}{r}-0.013 \\
(0.032)\end{array}$ & 576 & 0.046 \\
\hline Academic Engagement 2 & $\begin{array}{r}1.970 \\
(0.766)\end{array}$ & $\begin{array}{r}-0.095 \\
(0.061)\end{array}$ & 577 & 0.070 \\
\hline Careless Answering & $\begin{array}{r}-0.048 \\
(0.996)\end{array}$ & $\begin{array}{r}-0.028 \\
(0.078)\end{array}$ & 578 & 0.329 \\
\hline Item Non-Response Rate ${ }^{\wedge}$ & $\begin{array}{r}0.325 \\
(0.465) \\
\end{array}$ & $\begin{array}{r}-0.115^{* *} \\
(0.049) \\
\end{array}$ & 774 & 0.159 \\
\hline \multicolumn{5}{|l|}{ College-Going Behaviors } \\
\hline Conversations w/ School Staff & $\begin{array}{r}0.910 \\
(0.550)\end{array}$ & $\begin{array}{r}0.046 \\
(0.030)\end{array}$ & 577 & 0.145 \\
\hline Conversations w/ Parents & $\begin{array}{r}1.933 \\
(0.805)\end{array}$ & $\begin{array}{r}-0.020 \\
(0.047)\end{array}$ & 575 & 0.143 \\
\hline \multicolumn{5}{|l|}{ Postsecondary Intentions } \\
\hline Find a Job & 0.086 & $\begin{array}{r}0.003 \\
(0.025)\end{array}$ & 566 & 0.059 \\
\hline Enter the Military & 0.021 & $\begin{array}{r}0.042 \\
(0.024)\end{array}$ & 566 & 0.039 \\
\hline Attend a Technical School & 0.038 & $\begin{array}{r}-0.035 * * \\
(0.012)\end{array}$ & 566 & 0.059 \\
\hline Attend a Community College & 0.117 & $\begin{array}{r}-0.008 \\
(0.020)\end{array}$ & 566 & 0.021 \\
\hline Attend a 4-Year University & 0.684 & $\begin{array}{r}0.005 \\
(0.042)\end{array}$ & 566 & 0.096 \\
\hline
\end{tabular}

$* p<0.1, * * p<0.05, * * * p<0.01$

School fixed effects and self-reported feelings of college efficacy at baseline included in all models

Standard errors clustered at the school level

${ }^{\wedge}$ Students completely missing a spring survey are included in this analysis 
Table 6: Impact of Campus Visits on Ninth Grade Advanced Course-Taking (Probit, Marginal Effects Presented)

(1) (2)

(3)

(4)

Advanced Math Advanced ELA Advanced Sci/Soc. Sci Any Advanced

Assigned to Visits

$$
\begin{array}{r}
\mathbf{0 . 0 6 4 *} \\
(\mathbf{0 . 0 3 6 )}
\end{array}
$$

0.016

(0.033)

$0.061 *$

(0.034)

0.059

(0.039)

Observations

552

746

467

746

Assigned to Visits

0.038

(0.035)

0.094

$\mathbf{0 . 0 1 0}$

(0.034)

Baseline College

Efficacy

$0.122 * *$

(0.057)

(0.050)

(0.023)

0.046

(0.035)

$0.150 * * *$

$0.168^{* * *}$

$(0.062)$

492

653

412

(0.056)

Observations

*** $p<0.01, * * p<0.05, * p<0.1$

School fixed effects included in all models

Standard errors clustered at the school level 


\section{Appendix A: Detailed Descriptions of Campus Visits}

\section{A. Visit One}

The first campus visit included a college information session and campus tour. Students arrived on campus and met with Student Ambassadors from the college admissions office. The Student Ambassadors led the students around on a campus tour, highlighting traditions, history, and unique buildings. The eighth graders then participated in a workshop the College Access Initiative developed, which presented students with information about what college is, how to succeed in college, and how to prepare for college throughout middle and high school. The workshop covered study tips, the benefits of enrolling in advanced classes and participating in extracurricular activities in high school, as well as what resources, such as school counselors, are available throughout high school. The students also heard from current undergraduate students about their experiences and were able to ask questions about college life more broadly. To conclude the first visit, students had lunch in a central dining hall, where they were exposed to a variety of food options and were able to observe and interact with college students.

\section{B. Visit Two}

The second visit to campus focused on exposing students to different departments and degree paths available at the university. Students took a tour of housing options available on campus, which included seeing a model dorm room and the common areas that are standard in community-style housing halls. Following a tour of housing, the students participated in an engineering presentation. Current engineering students described various engineering subfields and their associated career paths. The engineering students then tasked the eighth graders with constructing an object from newspaper and tape to emphasize the skills of planning, problemsolving, and using scarce resources efficiently. Some groups built a tower that could stand on its 
own, while other students created a chain that could lift a bucket filled with water bottles. Teams won a prize if they built the tallest tower or strongest chain. Following the engineering program and lunch, students broke into smaller groups and visited another department on campus. The participating departments included English, architecture, economics, nursing, the Volunteer Action Center, astronomy, University Recreation, and theatre. Each department organized a content-specific activity for the students.

- English - Students who visited the English department participated in a creative writing workshop and wrote poetry that could be published in an annual poetry anthology written by K-12 students around the state that the department publishes.

- Architecture - Students discussed the different subfields of architecture and received a tour of the architecture building, which included student labs, a laser cutter, and a rooftop lounge.

- Economics - Students learned about financial stability and played games in which they were able to make various choices and learned how those choices would likely affect their long-term financial wellbeing.

- Nursing - Nursing students created stations where they could demonstrate standard body checks to the students. Eighth graders learned how and where on the body to check for a pulse, how to bandage wounds, and about reflex checks in patients' knees and elbows.

- The Volunteer Action Center - Students toured an on-campus food pantry and learned about various volunteer opportunities on campus.

- Physics - Faculty and undergraduate students who participate in the campus's astrophysics club taught students about the life cycle of stars and other astrological phenomena. 
- University Recreation - Students went to the largest gym on campus, learned about various recreational options on campus, and played a game of basketball.

- Theatre - Students visited a theatre set for a current university production and learned about multiple components of theatre, including acting, costumes, and set design.

\section{Visit Three}

For students' third visit to campus, schools choose between attending a Saturday afternoon baseball game featuring the university's baseball team or participating in an oncampus scavenger hunt during normal school hours. Students who attended the baseball game experienced a variety of fan traditions and cheered the university's team to victory. The research

team provided snacks and beverages throughout the game. The scavenger hunt was also designed by the research team to further familiarize students with campus and to help them learn some of the traditions and stories that create a campus community. In teams, students visited a variety of buildings on campus, participated in mock office hours, and completed a series of challenges (such as the university's main cheer). Teams uploaded pictures and videos of themselves completing the task to a private photo-sharing account so members of the research team could determine which team won. Winning teams were awarded medals emblazoned with the university's mascot or a trophy. After the scavenger hunt, students finished the day by eating lunch at the on-campus dining hall. 


\section{Appendix B}

Table B.1: Impact of Campus Visits on Survey-Based Outcomes; Controlling for School and Student Demographics

\begin{tabular}{|c|c|c|c|c|}
\hline & $\begin{array}{r}\text { Control Mean } \\
\text { (S.D.) }\end{array}$ & $\begin{array}{r}\text { Treatment Effect } \\
\text { (Cluster-Robust S.E) }\end{array}$ & $\mathbf{N}$ & R-Squared \\
\hline \multicolumn{5}{|l|}{ College Knowledge } \\
\hline College Knowledge & $\begin{array}{r}0.558 \\
(0.230)\end{array}$ & $\begin{array}{r}0.035 * * \\
(0.016)\end{array}$ & 616 & 0.118 \\
\hline \multicolumn{5}{|l|}{ Non-Cognitive Skills } \\
\hline College Efficacy & $\begin{array}{r}3.201 \\
(0.876)\end{array}$ & $\begin{array}{r}0.040 \\
(0.059)\end{array}$ & 622 & 0.1044 \\
\hline Grit & $\begin{array}{r}3.192 \\
(0.530)\end{array}$ & $\begin{array}{r}0.039 \\
(0.043)\end{array}$ & 617 & 0.036 \\
\hline Self-Management & $\begin{array}{r}4.057 \\
(0.656)\end{array}$ & $\begin{array}{r}0.008 \\
(0.050)\end{array}$ & 617 & 0.081 \\
\hline Perspective & $\begin{array}{r}3.365 \\
(0.700)\end{array}$ & $\begin{array}{r}-0.020 \\
(0.062)\end{array}$ & 618 & 0.045 \\
\hline Academic Engagement 1 & $\begin{array}{r}2.923 \\
(0.361)\end{array}$ & $\begin{array}{r}-0.000 \\
(0.025)\end{array}$ & 619 & 0.049 \\
\hline Academic Engagement 2 & $\begin{array}{r}1.970 \\
(0.766)\end{array}$ & $\begin{array}{r}-0.058 \\
(0.056)\end{array}$ & 621 & 0.051 \\
\hline Careless Answering (Std) & $\begin{array}{r}-0.048 \\
(0.996)\end{array}$ & $\begin{array}{r}0.051 \\
(0.091)\end{array}$ & 622 & 0.085 \\
\hline Item Non-Response Rate ${ }^{\wedge}$ & $\begin{array}{r}0.325 \\
(0.465) \\
\end{array}$ & $\begin{array}{r}-0.100 * * \\
(0.045) \\
\end{array}$ & 835 & 0.148 \\
\hline \multicolumn{5}{|l|}{ College-Going Behaviors } \\
\hline Conversations w/ School Staff & $\begin{array}{r}0.910 \\
(0.550)\end{array}$ & $\begin{array}{r}0.081 * * * \\
(0.219)\end{array}$ & 621 & 0.126 \\
\hline Conversations w/ Parents & $\begin{array}{r}1.933 \\
(0.805) \\
\end{array}$ & $\begin{array}{r}0.032 \\
(0.055) \\
\end{array}$ & 619 & 0.043 \\
\hline \multicolumn{5}{|l|}{ Postsecondary Intentions } \\
\hline Find a Job & 0.086 & $\begin{array}{r}0.003 \\
(0.022)\end{array}$ & 608 & 0.056 \\
\hline Enter the Military & 0.021 & $\begin{array}{r}0.038 \\
(0.023)\end{array}$ & 608 & 0.048 \\
\hline Attend a Technical School & 0.038 & $\begin{array}{r}-0.036 * * * \\
(0.012)\end{array}$ & 608 & 0.066 \\
\hline Attend a Community College & 0.117 & $\begin{array}{r}-0.006 \\
(0.021)\end{array}$ & 608 & 0.309 \\
\hline Attend a 4-Year University & 0.684 & $\begin{array}{r}0.005 \\
(0.042)\end{array}$ & 608 & 0.077 \\
\hline
\end{tabular}

$* p<0.1, * * p<0.05, * * * p<0.01$

School fixed effects included in all models; controls for student gender) and race included in all models

Standard errors clustered at the school level

${ }^{\wedge}$ Students completely missing a spring survey are included in this analysis 
Table B.2: Impact of Campus Visits on Survey-Based Outcomes; Controlling for School, Student Demographics, and Baseline College Efficacy

\section{Control Mean Treatment Effect}

(S.D.) (Cluster-Robust S.E)

\section{N R-Squared}

\begin{tabular}{|c|c|c|c|c|}
\hline \multicolumn{5}{|l|}{ College Knowledge } \\
\hline College Knowledge & $\begin{array}{r}0.558 \\
(0.230)\end{array}$ & $\begin{array}{r}0.045 * * \\
(0.017)\end{array}$ & 568 & 0.158 \\
\hline \multicolumn{5}{|l|}{ Non-Cognitive Skills } \\
\hline College Efficacy & $\begin{array}{r}3.201 \\
(0.876)\end{array}$ & $\begin{array}{r}-0.003 \\
(0.049)\end{array}$ & 574 & 0.448 \\
\hline Grit & $\begin{array}{r}3.192 \\
(0.530)\end{array}$ & $\begin{array}{r}0.024 \\
(0.043)\end{array}$ & 569 & 0.063 \\
\hline Self-Management & $\begin{array}{r}4.057 \\
(0.656)\end{array}$ & $\begin{array}{r}-0.033 \\
(0.044)\end{array}$ & 569 & 0.160 \\
\hline Perspective & $\begin{array}{r}3.365 \\
(0.700)\end{array}$ & $\begin{array}{r}-0.051 \\
(0.068)\end{array}$ & 571 & 0.107 \\
\hline Academic Engagement 1 & $\begin{array}{r}2.923 \\
(0.361)\end{array}$ & $\begin{array}{r}-0.016 \\
(0.033)\end{array}$ & 572 & 0.053 \\
\hline Academic Engagement 2 & $\begin{array}{r}1.970 \\
(0.766)\end{array}$ & $\begin{array}{r}-0.087 \\
(0.058)\end{array}$ & 573 & 0.092 \\
\hline Careless Answering & $\begin{array}{r}-0.048 \\
(0.996)\end{array}$ & $\begin{array}{r}-0.027 \\
(0.076)\end{array}$ & 574 & 0.334 \\
\hline Item Non-Response Rate ${ }^{\wedge}$ & $\begin{array}{r}0.325 \\
(0.465) \\
\end{array}$ & $\begin{array}{r}-0.113^{* *} \\
(0.049) \\
\end{array}$ & 768 & 0.163 \\
\hline \multicolumn{5}{|l|}{ College-Going Behaviors } \\
\hline Conversations w/ School Staff & $\begin{array}{r}0.910 \\
(0.550)\end{array}$ & $\begin{array}{r}0.044 \\
(0.030)\end{array}$ & 573 & 0.153 \\
\hline Conversations w/ Parents & $\begin{array}{r}1.933 \\
(0.805)\end{array}$ & $\begin{array}{r}-0.021 \\
(0.047)\end{array}$ & 571 & 0.146 \\
\hline \multicolumn{5}{|l|}{ Postsecondary Intentions } \\
\hline Find a Job & 0.086 & $\begin{array}{r}0.002 \\
(0.025)\end{array}$ & 562 & 0.074 \\
\hline Enter the Military & 0.021 & $\begin{array}{r}0.042 \\
(0.024)\end{array}$ & 562 & 0.051 \\
\hline Attend a Technical School & 0.038 & $\begin{array}{r}-0.037 * * \\
(0.012)\end{array}$ & 562 & 0.147 \\
\hline Attend a Community College & 0.117 & $\begin{array}{r}-0.002 \\
(0.021)\end{array}$ & 562 & 0.039 \\
\hline Attend a 4-Year University & 0.684 & $\begin{array}{r}0.004 \\
(0.041)\end{array}$ & 562 & 0.112 \\
\hline
\end{tabular}

${ }^{*} p<0.1, * * p<0.05, * * * p<0.01$

School fixed effects and self-reported feelings of college efficacy at baseline included in all models

Standard errors clustered at the school level

${ }^{\wedge}$ Students completely missing a spring survey are included in this analysis 
Table B.3: Impact of Campus Visits on Ninth Grade Advanced Course-Taking; Controlling for Student Demographics (Probit, Marginal Effects Presented)

(1) (2) (3)

Advanced Math Advanced ELA Advanced Sci/Soc. Sci
(4)

Any Advanced

\begin{tabular}{|c|c|c|c|c|}
\hline Assigned to Visits & $\begin{array}{c}0.064 * \\
(0.033)\end{array}$ & $\begin{array}{r}0.012 \\
(0.036)\end{array}$ & $\begin{array}{c}0.057 * \\
(0.034)\end{array}$ & $\begin{array}{r}0.055 \\
(\mathbf{0 . 0 4 1})\end{array}$ \\
\hline \multirow[t]{2}{*}{ Female } & $0.080 * * *$ & 0.061 & 0.018 & $0.093 * *$ \\
\hline & $(0.030)$ & $(0.048)$ & $(0.038)$ & $(0.043)$ \\
\hline \multirow[t]{2}{*}{ White } & $0.194 * * *$ & $0.243 * * *$ & 0.109 & $0.250 * * *$ \\
\hline & $(0.051)$ & $(0.035)$ & $(0.098)$ & $(0.076)$ \\
\hline \multirow[t]{2}{*}{ Latino/a } & $0.176 * * *$ & $0.166 * * *$ & & $0.203 * * *$ \\
\hline & $(0.046)$ & (0.033) & & $(0.072)$ \\
\hline \multirow[t]{2}{*}{ Other Race } & $0.209 * *$ & $0.264 * * *$ & 0.159 & $0.298 * * *$ \\
\hline & $(0.082)$ & $(0.051)$ & $(0.107)$ & (0.108) \\
\hline Observations & 544 & 716 & 465 & 716 \\
\hline \multirow[t]{2}{*}{ Assigned to Visits } & 0.039 & 0.009 & 0.033 & 0.045 \\
\hline & $(0.032)$ & $(\mathbf{0 . 0 3 5})$ & $(0.024)$ & $(0.036)$ \\
\hline \multirow[t]{2}{*}{ Baseline College Efficacy } & 0.085 & $0.114 * *$ & $0.149 * * *$ & $0.153 * * *$ \\
\hline & $(0.064)$ & $(0.055)$ & $(0.050)$ & $(0.055)$ \\
\hline \multirow[t]{2}{*}{ Female } & $0.093 * * *$ & 0.046 & 0.011 & $0.091 * * *$ \\
\hline & $(0.025)$ & $(0.048)$ & $(0.026)$ & $(0.034)$ \\
\hline \multirow[t]{2}{*}{ White } & $0.175^{* * *}$ & $0.241 * * *$ & 0.052 & $0.215^{* * *}$ \\
\hline & $(0.057)$ & $(0.037)$ & $(0.147)$ & $(0.084)$ \\
\hline \multirow[t]{2}{*}{ Latino/a } & $0.190 * * *$ & $0.156 * * *$ & & 0.169 \\
\hline & $(0.069)$ & $(0.036)$ & & $(0.103)$ \\
\hline \multirow[t]{2}{*}{ Other Race } & $0.217 * *$ & $0.293 * * *$ & 0.089 & $0.271 * *$ \\
\hline & $(0.106)$ & $(0.050)$ & $(0.174)$ & $(0.124)$ \\
\hline Observations & 491 & 649 & 412 & 649 \\
\hline
\end{tabular}

$* * * p<0.01, * * p<0.05, * p<0.1$

Standard errors clustered at the school level

School fixed effects included in all models 